\title{
aHUS caused by complement dysregulation: new therapies on the horizon
}

\author{
Aoife M. Waters $\cdot$ Christoph Licht
}

Received: 15 February 2010 /Revised: 23 April 2010 /Accepted: 26 April 2010 /Published online: 18 June 2010

(C) IPNA 2010

\begin{abstract}
Atypical hemolytic uremic syndrome (aHUS) is a heterogeneous disease that is caused by defective complement regulation in over $50 \%$ of cases. Mutations have been identified in genes encoding both complement regulators [complement factor $\mathrm{H}(\mathrm{CFH})$, complement factor I (CFI), complement factor H-related proteins (CFHR), and membrane cofactor protein (MCP)], as well as complement activators [complement factor $\mathrm{B}$ (CFB) and $\mathrm{C} 3$ ]. More recently, mutations have also been identified in thrombomodulin (THBD), an anticoagulant glycoprotein that plays a role in the inactivation of $\mathrm{C} 3 \mathrm{a}$ and $\mathrm{C} 5 \mathrm{a}$. Inhibitory autoantibodies to $\mathrm{CFH}$ account for an additional $5-10 \%$ of cases and can occur in isolation or in association with mutations in CFH, CFI, CFHR 1, 3, 4, and MCP. Plasma therapies are considered the mainstay of therapy in aHUS secondary to defective complement regulation and may be administered as plasma infusions or plasma exchange. However, in certain cases, despite initiation of plasma
\end{abstract}

Electronic supplementary material The online version of this article (doi:10.1007/s00467-010-1556-4) contains supplementary material, which is available to authorized users.

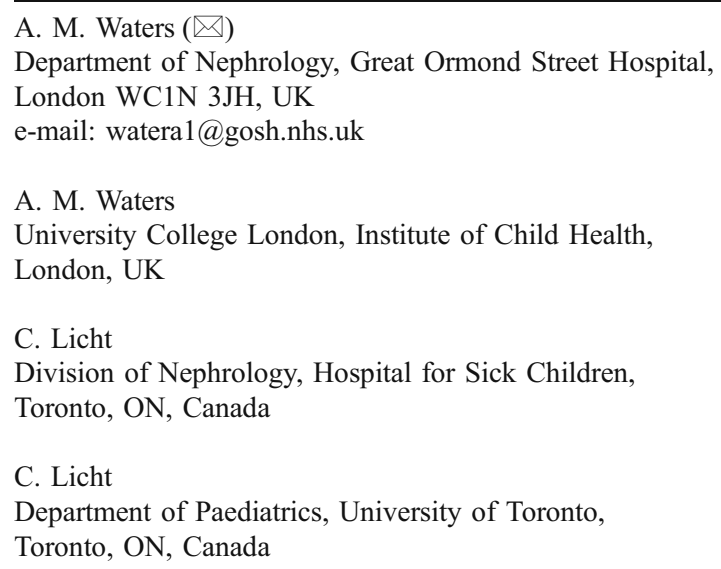

therapy, renal function continues to deteriorate with progression to end-stage renal disease and renal transplantation. Recently, eculizumab, a humanized monoclonal antibody against $\mathrm{C} 5$, has been described as an effective therapeutic strategy in the management of refractory aHUS that has failed to respond to plasma therapy. Clinical trials are now underway to further evaluate the efficacy of eculizumab in the management of both plasma-sensitive and plasma-resistant aHUS.

Keywords Atypical hemolytic uremic syndrome. Defective complement regulation Plasma therapy · Eculizumab

\section{Introduction}

As the most common cause of acute renal failure in childhood, hemolytic uremic syndrome (HUS) is a clinical entity that arises as a result of a systemic thrombotic microangiopathy (TMA). Characterized by the triad of a microangiopathic hemolytic anemia, thrombocytopenia, and acute renal failure, over $90 \%$ of childhood HUS results from infection with Shiga-toxin producing Escherichia coli (STEC) and 'typically' presents with a diarrheal prodrome $[1,2]$. Accounting for the remaining $10 \%$ of childhood HUS, atypical HUS (aHUS) is a heterogeneous disease that is associated with defective regulation of the alternative complement pathway in over $50 \%$ of cases (Table 1) [1, 36]. Mutations have been identified in genes encoding both complement regulators [complement factor $\mathrm{H}(\mathrm{CFH})$ [713], complement factor I (CFI) [14-24], complement factor H-related proteins (CFHR 1/3 and CFHR 1/4A) [1, 25, 26] and membrane cofactor protein (MCP) [27-31] in addition to complement activators [complement factor B (CFB) [18, 
Table 1 Etiology and classification of hemolytic uremic syndrome (HUS)
1. Infection-induced HUS

(a) Shiga and vero-cytotoxin (Shiga-like) producing bacteria

(b) Streptococcus pneumonia

2. Defective Complement Regulation

(a) Genetic defects of complement regulation e.g. factor $\mathrm{H}$ deficiency

(b) Acquired defects of complement regulation e.g. factor $\mathrm{H}$ autoantibodies

3. Defective ADAMTS13 function

(a) Genetic deficiency of ADAMTS13

(b) Acquired inhibition e.g. ADAMTS13 autoantibodies

4. Genetic deficiency of thrombomodulin

5. Defective cobalamine metabolism

6. Miscellaneous

a. Quinine-induced HUS (antibodies to platelet glycoproteins)

b. HIV

c. Pregnancy

d. Calcineurin-induced HUS

e. Malignancy

f. Systemic lupus erythematosus and antiphospholipid syndrome
$32,33]$ and $\mathrm{C} 3[34,35]$. An additional $6-10 \%$ of aHUS cases are associated with inhibitory $\mathrm{CFH}$ autoantibodies that block the C-terminal recognition domain of $\mathrm{CFH}$ and reduce $\mathrm{CFH}$ binding to $\mathrm{C} 3[25,36]$. The majority of patients with $\mathrm{CFH}$ autoantibodies are also deficient for CFHR1, which shares structural and functional similarities to $\mathrm{CFH}$ and inhibits $\mathrm{C} 5$ convertase activity and thereby terminal complex formation [26, 37]. More recently, CFH autoantibodies have also been associated with mutations in other complement regulators such as $\mathrm{CFH}, \mathrm{CFI}$, and CD46 (MCP) [38]. Furthermore, mutations in thrombomodulin (THBD), an anticoagulant glycoprotein which regulates $\mathrm{C} 3 \mathrm{~b}$ inactivation by factor I were recently identified in a further $6-10 \%$ of aHUS cases, thereby confirming previous associations between the coagulation cascade and complement regulation [39,40]. A remaining $40 \%$ of aHUS cases are currently unaccounted for, and thereby necessitate investigation of additional susceptibility factors and demand further explanation of phenotypic presentation in pedigrees demonstrating incomplete penetrance. For a more detailed overview of the genetic etiology of aHUS, the reader is referred to several excellent reviews on this topic [5, 41-43].

In contrast to Stx-HUS, aHUS is associated with a poor long-term prognosis (Table 2), may be familial [44], and is characterized by frequent relapses [45] and progression to end-stage renal disease (ESRD) in at least $50 \%$ of cases [4]. Disease recurrence following isolated renal transplantation is high and has been reported to occur in up to $30-100 \%$ of aHUS patients depending on the underlying complement defect [27, 46, 47]. Increasingly, it is recognized that a combination of mutations in genes encoding complement components, single-nucleotide polymorphisms (SNPs) and risk haplotypes must be present for aHUS to manifest in an individual $[38,48,49]$. Consequently, determination of the optimum therapeutic strategy can be challenging. The aim of this review is to provide an overview of the published experience of plasma therapy in aHUS associated with defective complement regulation. A second aim of this review is to highlight emerging evidence for a role for new agents that target the terminal complement cascade and may be the treatment of choice in cases associated with multiple complement defects.

\section{Overview of complement activation and regulation}

Complement activation is a central component of the innate immune system, playing an important role in target opsonization, leucocyte recruitment, and cell lysis [50 53]. Complement can be activated by three major pathways: the alternative pathway (AP) is spontaneously and continuously active, the classical pathway (CP) is activated when antibodies bind their cognate antigen or the lectin pathway (LP), which is activated by the binding of mannose-binding lectin (MBL) to mannose residues on the surface of microorganisms. Complement activation occurs sequentially, beginning with initiation of activation, followed by $\mathrm{C} 3$ convertase activation and amplification, $\mathrm{C} 5$ convertase activation, which leads to assembly of the lytic membrane attack complex (MAC). The critical initiating step in complement activation is the cleavage of $\mathrm{C} 3$ to generate $\mathrm{C} 3 \mathrm{~b}$ and the formation of $\mathrm{C} 3$-convertase, which are protease complexes (AP, $\mathrm{C} 3 \mathrm{bBb} ; \mathrm{CP} / \mathrm{LP}, \mathrm{C} 2 \mathrm{AC} 4 \mathrm{~b}$ ) (Fig. 1). Further amplification of activated $\mathrm{C} 3 \mathrm{~b}$ occurs when $\mathrm{AP} \mathrm{C} 3 \mathrm{bBb}$ is generated by convertase-generated $\mathrm{C} 3 \mathrm{~b}$. Binding of $\mathrm{C} 3 \mathrm{~b}$ to the $\mathrm{C} 3$-convertase generates the $\mathrm{C} 5$ - 
Table 2 Summary of clinical outcome in patients with aHUS

\begin{tabular}{lllll}
\hline Genetic defect & Frequency & Response to short-term plasma therapy & Long-term outcome & $\begin{array}{c}\text { Outcome after kidney } \\
\text { transplantation }\end{array}$ \\
\hline CFH & $20-30 \%$ & $\begin{array}{c}\text { Rate of remission: } 60 \% \\
\text { (dose- and timing-dependent) } \\
\text { Rate of remission: } 30-40 \%\end{array}$ & Rate of death or ESRD: $70-80 \%$ & $\begin{array}{c}\text { Rate of recurrence: } \\
80-90 \%\end{array}$ \\
CFI & $4-10 \%$ & Rate of death or ESRD: $60-80 \%$ & $\begin{array}{c}\text { Rate of recurrence: } \\
80-90 \%\end{array}$ \\
$\begin{array}{l}\text { CFHR1 \& } 3 \text { with CFH } \\
\text { autoantibodies }\end{array}$ & $6 \%$ & Rate of remission: $70-80 \%$ & Rate of death or ESRD: $30-40 \%$ & Rate of recurrence: $20 \%$ \\
$\begin{array}{l}\text { MCP } \\
\text { CFB }\end{array}$ & $10-15 \%$ & No indication for therapy & Rate of ESRD or death: $<20 \%$ & $\begin{array}{c}\text { Rate of recurrence: } \\
15-20 \%\end{array}$ \\
C3 & $1-2 \%$ & Rate of remission: $30 \%$ & Rate of death or ESRD: $70 \%$ & $\begin{array}{c}\text { Recurrence in one case } \\
\text { Rate of recurrence: } \\
40-50 \%\end{array}$ \\
THBD & $5-10 \%$ & Rate of remission: $40-50 \%$ & Rate of death or ESRD: $60 \%$ & Recurrence in one case \\
\hline
\end{tabular}

convertase with the capacity to bind and cleave C5, initiating formation of the MAC.

Under normal circumstances, circulatory $\mathrm{C} 3$ activation is low and is a tightly regulated process under the control of four major classes of regulatory proteins: fluid phase complement regulators, membrane-bound complement regulators, complement receptors, and surface-bound complement regulators [43] (Fig. 1). Regulation occurs at multiple steps including the inactivation of $\mathrm{C} 3 \mathrm{~b}$ or $\mathrm{C} 4 \mathrm{~b}$, the dissociation of the $\mathrm{C} 3 / \mathrm{C} 5$ convertase, or the inhibition MAC formation. Fluid-phase regulators circulate in plasma and include the alternative pathway regulators, complement factor $\mathrm{H}(\mathrm{CFH})$, and factor $\mathrm{H}$-like protein (FHL), glyco-

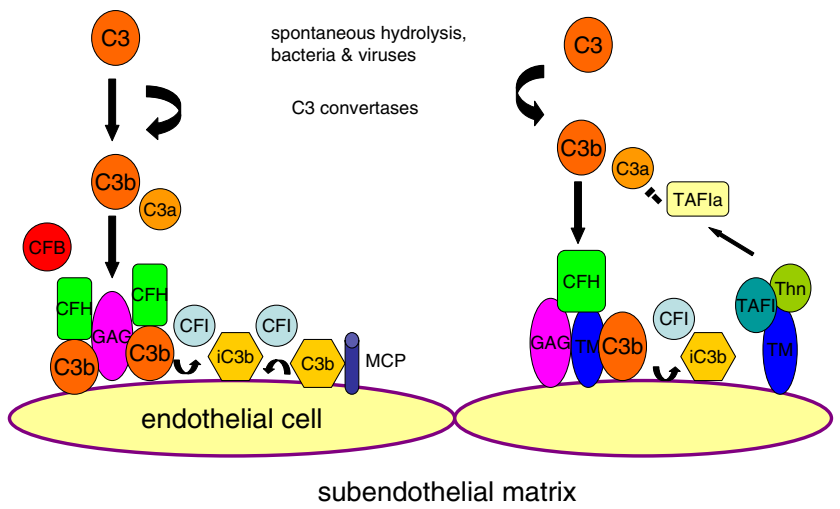

Fig. 1 Activation and regulation of the alternative complement pathway. Complement factor $\mathrm{H}$ binds to the endothelial cell surface, $\mathrm{C} 3 \mathrm{~b}$, and with membrane co-factor protein (MCP), acts as a co-factor for cleavage of $\mathrm{C} 3 \mathrm{~b}$. This process is mediated by complement factor I. This presents the formation of $\mathrm{C} 3 \mathrm{bBb}$ complex. Dissociation of the $\mathrm{C} 3$ convertase is also mediated by factor $\mathrm{H}$. Thrombomodulin enhances factor-I- mediated cleavage of $\mathrm{C} 3 \mathrm{~b}$ in the presence of factor $\mathrm{H}$ and promotes activation of TAFIa (thrombin activatable fibrinolysis inhibitor), which degrades $\mathrm{C} 3 \mathrm{a}$ and $\mathrm{C} 5 \mathrm{a}$. $A b$ antibody; $C F B$ complement factor B; $C F H$ complement factor $\mathrm{H}$; $C F I$ complement factor I; $T M$ thrombomodulin; $M C P$ membrane cofactor protein; TAFIa thrombin activatable fibrinolysis inhibitor; Thn thrombin proteins that are synthesized in the liver. FHL-1 is an alternative splice product of $\mathrm{CFH}$ [52]. $\mathrm{CFH}$ regulates complement activation by at least three different mechanisms (Fig. 1). Firstly, CFH binds to CFI, a serine protease that mediates the proteolytic cleavage of the $\alpha$-chain of $\mathrm{C} 3 \mathrm{~b}$ resulting in the formation of iC3b (co-factor activity) [54]. Following further cleavage by $\mathrm{CFI}, \mathrm{iC} 3 \mathrm{~b}$ forms the $\mathrm{C} 3 \mathrm{dg}$ and $\mathrm{C} 3 \mathrm{c}$ fragments using the membrane-bound complement receptor 1 (CR1 or CD35) [55, 56]. A second function of $\mathrm{CFH}$ includes the inhibition of the interaction between $\mathrm{C} 3 \mathrm{~b}$ and CFB and thereby blocks the formation of the $\mathrm{C} 3 \mathrm{bBb}$ convertase complex (decay-accelerating activity). Furthermore, $\mathrm{CFH}$ promotes the dissociation of $\mathrm{C} 3$ convertase once they have formed (decay-accelerating activity). Binding of $\mathrm{CFH}$ by its $\mathrm{C}$-terminus to sialic acid, glycosaminoglycans, or sulfated polysaccharides (heparin) increases the affinity of $\mathrm{CFH}$ for surface-bound $\mathrm{C} 3 \mathrm{~b}$. Additional regulation is further achieved by the presence of five structurally related proteins to CFH (CFHR1-5) and are all composed of short consensus repeats (SCRs) that share different degrees of identity with SCRs in CFH [57]. A regulatory function for CFHR1-5 proteins is suggested by their ability to bind C3b. Recent work has shown that CFHR1 blocks $\mathrm{C} 5$ convertase activity and interferes with $\mathrm{C} 5 \mathrm{~b}$ surface deposition and MAC formation [26, 58]. Similar to CFH, CFHR proteins are also synthesized in the liver but are present in much lower concentrations compared to CFH. In addition to regulation within the fluid phase, regulation also occurs at the level of the cell membrane. Several membrane-bound proteins have been shown to regulate complement and include complement receptors 1 and 2, complement decay accelerating factor (DAF), membranebound cofactor protein (MCP; CD46), protectin (CD59), and complement receptor of the immunoglobulin superfamily (CRIg) (Fig. 1). Membrane-bound factors control the three major complement activation pathways and 
inactivate both $\mathrm{C} 3$ and $\mathrm{C} 4$. Fluid-phase regulators, on the other hand, are more specific and regulate either the alternative, classical, or the lectin pathways and act almost exclusively on either $\mathrm{C} 3$ or $\mathrm{C} 4$.

\section{Investigation of aHUS during disease flares}

Management of an aHUS crisis first begins with recognition and diagnosis. Clinically, HUS presents with a triad of microangiopathic hemolytic anemia (fragmented erythrocytes with low haptoglobin levels), thrombocytopenia, and acute renal failure. As set out in detail in the report published in 2006 by the European Study Group for HUS, the classification of HUS, thrombotic thrombocytopenic purpura (TTP) and related disorders is summarized in Table 1. An aHUS crisis occurring secondary to defective complement regulation should be considered if the following features are present: presentation before 6 months of age, insidious onset, previous episode of HUS, previous unexplained anemia, asynchronous family history of HUS or HUS post-transplantation of any organ, as recently described in the 'Guidelines for the Investigation and Initial Therapy of Diarrhoea-Negative Hemolytic Uremic Syndrome' published by the European Study Group for HUS [3]. Investigation for enterohemorrhagic Escherichia coli should still be undertaken in the context of atypical features, as unusual presentations have been known to occur [59].

If a patient is suspected of having aHUS, then measurement of plasma complement $\mathrm{C} 3, \mathrm{C} 4, \mathrm{CFH}, \mathrm{CFH}$ autoantibodies, CFI and CFB levels, and surface expression of MCP (CD46) on mononuclear leucocytes by FACS should be undertaken (Table 3). Furthermore, genetic mutation analysis for the susceptibility genes, $\mathrm{CFH}, \mathrm{CFI}$, CFHR1-5, CFB, CD46, and C3 should also be undertaken. If a patient has had a blood transfusion, then it is advisable to wait for 2 weeks before undertaking any mutational analysis. Details of the laboratories offering specialized investigation can be found on the following Web site: http:// espn.cardiff.ac.uk.

It is important to note that while low levels of C3 may indicate complement dysregulation, there are occasions when C3 levels are normal [60]. Activation of the alternative pathway may still be a feature and measurement of serum MAC and $\mathrm{iC} 3 \mathrm{~b}$ may prove to be a more useful indicator of alternative pathway activity with sMAC indicating the degree of activation of the terminal complement cascade and $\mathrm{iC} 3 \mathrm{~b}$ indicating the degree of inactivation of $\mathrm{C} 3 \mathrm{~b}$. Elevated $\mathrm{C} 3 \mathrm{~d}$ levels are also an indicator of alternative pathway activation. Where $\mathrm{C} 3$ levels are normal, genetic investigation is still clearly warranted in such cases of aHUS [41, 60]. Furthermore, recent evidence has demonstrated that mutations in several complement genes can manifest in any one individual and therefore, mutation screening should be undertaken for all predisposing genes if possible. A summary of the known disease-causing mutations can be found on the following Web site: www. fh-hus.org and have been reviewed in detail elsewhere in this series. Careful consideration should also be given to other causes of aHUS, such as disorders of cobalamin metabolism as well as ADAMTS13 activity (a disintegrin and metalloprotease with thrombospondin motifs). While beyond the scope of this article, the reader is referred to

Table 3 Diagnostic tests for complement activation in aHUS

\begin{tabular}{|c|c|c|c|}
\hline $\begin{array}{l}\text { Complement } \\
\text { proteins }\end{array}$ & Plasma concentration & Technique & Interpretation \\
\hline $\mathrm{C} 3$ & $660-1,250 \mathrm{mg} / \mathrm{l}$ & Nephelometry & $\begin{array}{l}\text { Hypocomplementemia is strongly suggestive } \\
\text { of alternative pathway activation in aHUS }\end{array}$ \\
\hline APH50 & $50-125 \%$ & Radio immunodiffusion & $\begin{array}{l}\text { Elevation suggests activation of the } \\
\text { alternative pathway }\end{array}$ \\
\hline $\mathrm{CH} 100$ & 311-827 Units & Radio immunodiffusion & \\
\hline $\mathrm{C} 3 \mathrm{dg} / \mathrm{C} 3 \mathrm{~d}$ & $<40 \mathrm{mU} / \mathrm{l}$ & $\begin{array}{l}\text { Double-decker rocket } \\
\text { immunoelectrophoresis, using anti-C } 3 \mathrm{c} \text { and } \\
\text { anti-C3d antibodies }\end{array}$ & \\
\hline CFB & $93-380 \mathrm{mg} / \mathrm{l}$ & Nephelometry & $\begin{array}{l}\text { Low CFB is suggestive of alternative } \\
\text { pathway activation in aHUS }\end{array}$ \\
\hline $\mathrm{CFH}$ & $330-680 \mathrm{mg} / \mathrm{l}$ & ELISA & $\mathrm{CFH}$ level less than $60 \%$ suggests deficiency \\
\hline $\mathrm{CFI}$ & $40-80 \mathrm{mg} / \mathrm{l}$ & ELISA & CFI level less than $60 \%$ suggests deficiency \\
\hline $\begin{array}{l}\text { Anti-CFH } \\
\text { autoantibody }\end{array}$ & Negligible & ELISA & $\begin{array}{l}\text { Autoantibodies against the } \mathrm{C} \text {-terminus are } \\
\text { thought to be pathogenic }\end{array}$ \\
\hline MCP & Mean fluorescence intensity & $\begin{array}{l}\text { Flow cytometry analysis with anti-MCP } \\
\text { phycoerythrin (PE)-conjugated antibodies }\end{array}$ & $\begin{array}{l}\text { Homozygous deficiency is associated with no } \\
\text { MCP expression. MFI is } 50 \% \text { in } \\
\text { heterozygous individuals }\end{array}$ \\
\hline
\end{tabular}


other reviews on these disorders regarding diagnosis and management [61, 62].

\section{Plasma therapy in aHUS associated with complement dysregulation}

Plasma therapy is considered the first-line therapy for aHUS [3, 6, 41, 63, 64]. While there have been no controlled clinical studies, the introduction of plasma therapy into the management of aHUS was associated with a decrease in mortality from 50 to $25 \%$ [65, 66]. Plasmabased therapies may be classified as plasma infusion (PI) or plasma exchange (PEX). Plasma infusion is thought to replace defective complement components and regulators with functional proteins $[67,68]$. Plasma exchange offers the additional advantage of removal of mutant $\mathrm{CFH}$, CFI, $\mathrm{CFB}, \mathrm{C} 3$, and $\mathrm{CFH}$ autoantibodies while restoring functional complement regulators.

Given the emerging evidence for the existence of a combination of complement defects and risk haplotypes in disease manifestation, it is no longer sufficient to consider the management of aHUS as simply a matter of replacing a single deficient factor by PI or removal of a mutant factor by PEX. As a result, the European Working Group on HUS has recently published consensus guidelines with the aim of establishing a standardized approach to the initial management of aHUS and thereafter with a view to auditing this approach again in 3 years [3]. As there have been no randomized controlled clinical trials investigating the efficacy of either PI or PEX in the management of aHUS, the published guidelines are expert consensus opinions based on combined personal experiences and published case reports.

Guidelines suggest that plasmapheresis should be commenced within $24 \mathrm{~h}$ of initial presentation along with supportive treatment (transfusion, dialysis, antihypertensive therapy). However, in clinical practice, this may not always be possible due to the time that it may take to rule out infection with for EHEC. Neurological symptoms in HUS can be a consequence of many factors such as cerebral microangiopathy with ischemia and infarction, hypertension, and cerebral edema arising from metabolic disturbances. The presence of these symptoms indicates a progressive disease process and following correction of hypertension and metabolic disturbances with dialysis, plasmapheresis should be instituted promptly in those cases suspected of having aHUS. Initially, 1.5 times the expected plasma volume should be exchanged or a plasma infusion of $20-30 \mathrm{ml} / \mathrm{kg}$ of body weight should be administered [3]. Replacement with whole plasma fraction such as virusinactivated pooled plasma or individual units of fresh frozen plasma (FFP) from screened donors is recommended
[69]. PEX may be achieved by plasma filtration or via a centrifugal separator, according to local practice and expertise. Daily PEX is recommended for the initial 5 days followed by five sessions per week for the next 2 weeks and then tapered to three sessions per week for the subsequent 2 weeks [3].

Following initiation of plasmapheresis, it is advisable to monitor the full blood count, electrolytes, and serum creatinine daily to determine whether the therapy has made any impact on the degree of hemolysis and renal dysfunction. Similarly, it may also be helpful, in those cases presenting with low $\mathrm{C} 3$ levels, to measure daily $\mathrm{C} 3$ levels throughout plasmapheresis to help determine the optimal therapeutic regime in individual cases for the management of subsequent disease flares. The current guidelines suggest that remission has been achieved if platelet counts are sustained $>150 \times 10^{9} / 1$ for 2 weeks and there has been no hemolysis as determined by the presence of fragmented red cells, elevated lactate dehydrogenase, and low haptoglobins [3]. Recurrence of thrombocytopenia and hemolysis after 2 weeks of recovery of both parameters signifies a relapse and reinstitution of plasmapheresis is recommended if previously successful. Furthermore, for auditing purposes, it is recommended that the renal function be graded as normal [glomerular filtration rate (GFR) $\geq 80 \mathrm{ml} / \mathrm{min} /$ $1.73 \mathrm{~m}^{2}$ as determined by the Schwartz formula or by a formal clearance assay], renal impairment whereby plasma creatinine level is elevated for age or GFR $<80 \mathrm{ml} / \mathrm{min} /$ $1.73 \mathrm{~m}^{2}$ or renal failure (requiring dialysis). Furthermore, the presence of proteinuria and hypertension (expressed as a centile based on age and gender) including number of antihypertensive agents should be recorded.

Following a period of 3 years, the European Study Group on aHUS aims to audit the proportion of cases investigated and the resultant yield from the proposed investigations to determine what proportion were treated according to the guidelines and the proportion that were withdrawn or did not meet the criteria for treatment according to the guidelines. Importantly, the objective of the recommended guidelines also propose to determine the proportion of patients entering hematological remission based on the recommended therapy schedule for the first month and those that have preserved or loss of renal function by the end of the first month.

\section{Summary of reported therapy response of individual complement regulatory defects}

With the advent of extended mutational analysis in aHUS patients, it is now very clear that disease manifestation is more frequently associated with a combination of risk factors that not only includes mutations in key complement 
components and regulators but also risk haplotypes and SNPs in other complement components. In the ensuing text, we review the published experience of either PI or PEX in cases that have previously been reported as defects in a single component. Response to plasma therapy in relation to underlying genetic defects should be interpreted with caution as it is possible that further defects would be found in such patients if they were to undergo further genetic screening. Therefore, the objective of the ensuing text is to highlight the outcome of individual cases based on the reported therapeutic regimen employed and thereby demonstrate the divergent outcomes even amongst those cases that appeared to have similar underlying genetic defects.

\section{$\mathrm{CFH}$}

Deficiency of CFH may be either quantitative or functional. A quantitative deficiency is defined as CFH plasma levels below half of normal [9]. Complete deficiency is extremely rare and is defined by the total absence or severe reduction in CFH levels. To date, $34 \mathrm{CFH}$-deficient patients have been described from 16 families [9, 70-81]. Renal disease has been reported in 28 of these 33 cases, of whom 16 developed aHUS [67, 72, 76-79, 82-85]. The clinical presentation of those with complete $\mathrm{CFH}$ deficiency and their complement profile, plasma therapy regimen, and outcome are summarized in Supplementary Table 1. If plasma therapy such as PI with FFP is initiated early in the course of the disease when the serum creatinine level is normal or only slightly elevated, then it may be possible to preserve renal function for a number of months or years [86]. However, as there may be more than one defect present, recommendations now advocate for PEX as the initial treatment regimen with the additional advantage of removal of mutant proteins while restoring functional proteins. Functional CFH deficiency is more common than complete CFH deficiency and is associated with a normal $\mathrm{CFH}$ level. While mutations have been found throughout the gene, over $80 \%$ occur within the region that encodes the C-terminal domain of the protein and results in reduced binding of $\mathrm{C} 3 \mathrm{~b}$ and to polyanions leading to impaired function of $\mathrm{CFH}$. For patients, with a functional deficiency of $\mathrm{CFH}$, the response to plasma exchange with FFP replacement has been shown to be effective [87-91] (Supplementary Table 2). As mutations of $\mathrm{CFH}$ are heterogeneous, a strategy of intensive and prophylactic PEX may not be necessary in all patients with $\mathrm{CFH}$ mutations and therapy should be tailored according to individual patient response. Furthermore, resistance to long-term plasma therapy has been reported in patients $[88,92]$. Although the underlying mechanisms for the development of resistance require investigation, a plausible reason may be the development of autoantibodies to $\mathrm{CFH}$ or other complement proteins for which assays are not readily available.

\section{Purified CFH concentrates}

As the strategy of prophylactic PEX is expensive, necessitates creation of an arteriovenous fistula, central venous access, and implies life-long regular treatment in a hospital, the development of a purified human plasma-derived $\mathrm{CFH}$ concentrate may provide sufficient $\mathrm{CFH}$ in a small volume to replace PEX and thereby reduce the risks associated with central venous access and volume overload. Whether it will suffice to administer it alone or in combination with PEX will have to be determined in the future. Development of such a concentrate is currently being undertaken by the Laboratoire Français du Fractionnement et des Biotechnologies (details can be found at the Web site: www.emea. europa.eu/pdfs/human/comp/opnion/52123506en.pdf).

Management of $\mathrm{CFH}$ autoantibodies during disease flares

Recent studies have suggested a pathogenic role for $\mathrm{CFH}$ autoantibodies in the development of aHUS [25, 93, 94]. Functional studies have demonstrated that $\mathrm{CFH}$ autoantibodies bind to the $\mathrm{C}$-terminus of $\mathrm{CFH}$ and thereby inhibit $\mathrm{C} 3 \mathrm{~b}$ binding, leading to enhanced complement activation and red cell hemolysis [95]. Furthermore, deficiency of the complement regulatory proteins, CFHR 1 and CFHR $1 /$ 3 , has also been described in patients with CFHautoantibody associated aHUS (Supplementary Table 3) $[25,38,96-98]$.

Current recommendations propose that a trial of PEX therapy is warranted in an attempt to remove $\mathrm{CFH}$ autoantibodies [21, 99]. PEX provides an excess of CFH that may saturate and neutralize the autoantibody activity and partially restore functional CFH circulating levels, while removing the autoantibody from the circulation [5]. In the pre-transplantation setting, intravenous immunoglobulin (IVIG) and rituximab (the anti-CD20 [67] antibody) have been utilized with efficacy in preventing recurrence post-transplantation and is described in detail in the section entitled 'Transplantation in aHUS'.

\section{CFI}

Mutations in CFI account for around $10 \%$ of aHUS cases [14] and similarly to $\mathrm{CFH}$, result in either a quantitative or functional deficiency of CFI protein [22]. A poor prognosis exists for aHUS associated with CFI mutations with over $50 \%$ of reported cases progressing to ESRD following initial presentation. Approximately $40 \%$ of CFI mutations result in low levels of CFI [33]. Therefore, replacement 
with plasma theoretically should restore deficient CFI in patients who have only CFI mutations. However, as outlined in Supplementary Table 4, the response to either PI alone or PEX is often inadequate and this may be due to the occurrence of concomitant complement defects or risk haplotypes that were not detected at the time of reporting.

\section{CFB}

Patients carrying CFB gain-of-function mutations develop aHUS as a result of decreased decay of the $\mathrm{C} 3 \mathrm{bBb}$ convertase [32]. Of four patients in whom details of treatment has been reported, plasma therapy was administered to three patients, with one patient receiving PEX only, one patient receiving PI only, and one patient receiving a combination of both. Disease progressed in all patients despite plasma therapy with four patients progressing to ESRD. The fourth patient, at the time of reporting, had moderate renal insufficiency but had not received plasma therapy. An additional patient who also carries a CFI mutation experienced immediate disease recurrence in the renal allograft following transplantation and despite treatment with intravenous immunoglobulin (IVIG), ESRD has progressed in the allograft almost 5 years later [47]. Patients carrying gain-of-function CFB mutations are likely to require very large amounts of FFP and very frequent PEX in order to overcome the overproduction and resistance to decay of the alternative pathway $\mathrm{C} 3$ convertase to $\mathrm{C} 3 \mathrm{bBb}$. This will need to be confirmed by serial measurements of complement during therapy in future studies.

\section{MCP}

Patients carrying MCP (CD46) mutations tend to recover completely from aHUS relapses [24, 46, 47]. None of the children reported so far develop ESRD at 1 year from initial presentation while $86 \%$ remain dialysis-free in the long term [24, 46, 47]. Evidence from individual case reports [20] in addition to the reports from the Italian [46] and French series [24] suggest that plasma therapy is unlikely to be of therapeutic benefit in CD46 mutation-associated aHUS. In the French series, favorable outcome occurred in eight $(89 \%)$ of nine episodes that were treated with plasma therapy and $15(88 \%)$ of 17 untreated episodes [24]. Caprioli et al. reported in the Italian series that complete or partial remission (defined by recovery of hematological parameters with persistence of renal dysfunction) was achieved in $91 \%$ of plasma-treated episodes but also in $100 \%$ of the non-treated episodes [46]. However, in those patients who did not recover spontaneously, it was not possible to conclude that plasma therapy failed because it was not adequately administered. Furthermore, a recently reported fifth case by Davin et al. was initially treated with daily PEX and recovered normal renal function [100]. However, recurrence of aHUS over the subsequent 4 years was associated with a progressive decline towards ESRD despite continuous prophylactic PEX. The lack of a response in aHUS patients carrying MCP mutations is likely owing to the fact that MCP is a membrane-bound protein and its role is limited to endothelial cells, and as a result, is not associated with systemic complement dysregulation.

\section{Transplantation in aHUS}

\section{Outcome}

Recurrence post-transplantation has been reported in three retrospective cohorts of aHUS patients with defective complement regulation [24, 46, 101]. Within the larger cohorts, mutations in CFH, CFI, or MCP were reported in around $50 \%$ of aHUS patients and post-transplant recurrence was reported in 33\% [24], 37\% [46], and 60\% [101] of grafts.

Transplantation in patients carrying $\mathrm{CFH}$ mutations is particularly unfavorable with an almost $80-100 \%$ recurrence rate reported, depending on the degree of quantitative deficiency of $\mathrm{CFH}$ and the concurrence of other complement defects. In one series, $74 \%$ of $\mathrm{CFH}$ mutated patients had HUS recurrence from 2 days to 22 months after transplantation; $93 \%(13 / 14)$ of recurrences induced graft loss, most often ( $85.7 \%$ of recurrences) within the year after recurrence. Only one of the 15 grafts with recurrence was functioning at 6 years of follow-up [101]. Similarly poor outcomes have been reported by the UK (78\%) [48], and Italian Registries (83\%) [46]. For those with CFI mutations, a similar rate of recurrence has been reported with 11 of 12 grafts failing in eight recipients due to disease recurrence $[15,20,36,47,102]$. While recurrence data for CFB and C3 mutations are also emerging [90, 103], conclusions regarding appropriate therapeutic strategies cannot be made until more cases are reported.

\section{Role of combined liver-kidney transplantation}

Combined liver-kidney transplantation has recently been advocated for patients with $\mathrm{CFH}$ and CFI mutations as $\mathrm{CFH}$ and CFI are circulating factors synthesized by the liver [6, 47, 104-106]. Justification for liver transplantation comes from the fact that mutant $\mathrm{CFH}$ or CFI will continue to be produced by the liver in those who receive a renal transplant only and therefore, recipient mutant $\mathrm{CFH}$ or CFI may still not regulate complement activation sufficiently in the donor renal allograft, thereby leaving it susceptible to disease recurrence. Initial reports of orthotopic liver transplantation in aHUS were disappointing with 
the first CFH-deficient recipient experiencing acute hepatic failure during the liver transplant [12]. A second liver was transplanted at day 26, resulting in aHUS remission, the patient later developed neurological sequelae from severe hepatic encephalopathy [107]. A 21/2-year-old was the second recipient who received a liver transplant from his father following severe, recurrent hemolytic/thrombocytopenic episodes but had preserved renal function. Following transplantation, the patient suffered fatal liver failure immediately following transplantation following a period of graft hypoperfusion that led to complement activation and microvascular thrombosis and infarction in the liver allograft. He died 10 months later from lymphoproliferative disease and recurrent infections associated with features of HUS [108]. However, despite the poor outcome for both of these cases, normalization of $\mathrm{CFH}$ levels posttransplantation was demonstrated for the first patient and recurrence was avoided in the second, thereby suggesting that combined liver-kidney transplantation may be an effective strategy for preventing disease recurrence in patients with aHUS. Subsequently, a modified approach was employed whereby pre-transplantation PEX was administered to remove mutant $\mathrm{CFH}$ in addition to peritransplantation PI after hepatectomy and before donor liver implantation, which led to increased bioavailability of $\mathrm{CFH}$ during acquisition of allograft liver function [106]. Furthermore, low-dose enoxaparin and aspirin were employed to counteract the enhanced thrombogenicity of the allograft endothelium [106]. Furthermore, a role for isolated liver transplantation may also be considered in patients who have frequent relapses but stable renal function. While a paucity of data exists, preliminary guidelines have been proposed based on experience drawn from about one dozen liverkidney transplants for aHUS worldwide over the past decade. Successful liver-kidney transplants have been undertaken in four centers worldwide and should be undertaken in an experienced center given the high rate of postoperative complications. It is likely that plasma requirements will vary between individuals to control complement activation which can be exacerbated on reperfusion of the transplanted liver. The amount of required plasma may also depend on how long it takes for the transplanted liver to establish its synthetic function and the rate of synthesis of complement regulatory proteins. Patients with surgical complications leading to prolonged warm ischemia and delayed liver graft function will probably require more plasma over an extended period.

Renal transplantation in CFH autoantibody-associated aHUS

A paucity of literature exists as to the success of isolated renal transplantation of patients with $\mathrm{CFH}$ autoantibodies.
Recently, Kwon and colleagues reported successful renal transplantation in a 10-year-old girl with $\mathrm{CFH}$ autoantibody-associated aHUS [99]. Prior to transplantation, therapy consisted of prednisolone, azathioprine, and PEX in an attempt to decrease the $\mathrm{CFH}$ autoantibody titre. A decrease in $\mathrm{CFH}$ autoantibody titres following six sessions of PEX $(50 \mathrm{ml} / \mathrm{kg} / \mathrm{session}$ over 15 days) was observed. On cessation of PEX, CFH autoantibody titers rose again within a month, but on initiation of a second course of PEX, subsequently decreased again, thereby suggesting a potential beneficial role for PEX in removing CFH autoantibodies [99]. No recurrence of disease occurred following an exchange program of $50 \mathrm{ml} / \mathrm{kg} / \mathrm{session}$ with FFP substitution immediately prior to surgery and continued daily during the first week following transplantation with subsequent tapering over the following 4 months [99]. HUS did not recur in the following 2 years posttransplantation. Further reports of successful renal transplantation in CFH-autoantibody-associated aHUS without recurrence have recently emerged and without adjuvant rituximab [38, 98]. Induction of immunosuppression with basiliximab, the IL2 receptor antagonist, in addition to high-dose corticosteroids and mycophenolate mofetil was utilized as a steroid-sparing agent and no disease recurrence, thereby suggesting that this immunosuppressive regimen may be efficacious in certain cases of $\mathrm{CFH}$ autoantibody-associated aHUS.

\section{Living-related organ donation}

Familial cases of aHUS associated with complement defects have been reported [30, 46, 109] and therefore, following presentation of the index case, it would be prudent to discuss the possibility of disease manifestation in other family members. In our opinion, urinalysis and blood pressure monitoring should be undertaken in all family members on at least an annual basis. If proteinuria or hypertension became evident, then further investigation of renal function, complement profile and genetic testing for complement defects may be warranted. In the event of transplantation, living-related organ donation is contraindicated in patients with $\mathrm{CFH}, \mathrm{CFI}, \mathrm{CFB}$, and $\mathrm{C} 3$ mutations owing to a significant recurrence risk in the renal allograft $[6,47]$. Owing to the incomplete penetrance of HUS associated with complement defects in family members, the genetic variability within family members in addition to a number of SNPs, living-related donation is not without risk. Furthermore, the remaining kidney in the donor may also be susceptible to disease manifestation where it has been previously reported that four donors developed HUS in their native kidneys following donation [47, 110]. If living-related donation is the only possible option, complete genotyping of all known complement 
abnormalities of the related donor should be performed. In the absence of a mutation or risk haplotype, the donor must be informed that there remains a possibility that he might have some unknown risk factor of developing HUS after kidney donation [47].

\section{Therapies affecting the terminal complement cascade}

\section{Eculizumab}

Emerging evidence has shown that patients presenting with aHUS can have a constellation of genetic defects that result in over-activation of the alternative complement cascade $[66,103]$. Such patients represent a significant therapeutic challenge and, as a result, disease flares may be best treated with agents that target the membrane attack complex (MAC) composed of C5b-9, the final effector pathway of complement activation. Eculizumab, a humanized monoclonal antibody against $\mathrm{C} 5$, has recently been shown to be an effective treatment in aHUS [100, 103, 111-113]. Initially, eculizumab was employed in the therapy of patients with paroxysmal nocturnal hemoglobinuria where it was shown to markedly reduce intravascular hemolysis, the need for transfusion, and patient fatigue $[114,115]$. It has also been shown to be effective in patients with rheumatoid arthritis, systemic lupus erythematosus, myocardial infarction, membranous nephritis, and those who have undergone coronary artery bypass surgery [116]. Biochemically, eculizumab is an $\mathrm{IgG}$ immunoglobulin comprised of human constant regions and murine complementarity determining regions grafted onto human framework light- and heavy-chain variable regions. Eculizumab is composed of two 448-amino-acid heavy chains and two 214-amino-acid light chains and has a molecular weight of approximately $148 \mathrm{kDa}$. Eculizumab does not inhibit C5 activity in animal sera but does bind to human tissues, including smooth and striated muscle as well as renal proximal epithelium. In animal studies, eculizumab was found to cross the placental barrier and show fetal morbidity and mortality [117]. Details can be found on the following Web site http://www.emea.europa.eu/human docs/Humans/EPAR/soliris/soliris.htm.

Mechanism of action

Complement $\mathrm{C} 5$ is split by $\mathrm{C} 5$ convertase into $\mathrm{C} 5 \mathrm{a}$ and $\mathrm{C} 5 \mathrm{~b}$ (Fig. 2a). C5a increases the permeability of blood vessels and attracts inflammatory cells by chemotaxis. $\mathrm{C} 5 \mathrm{~b}$ binds to other complement components (C6, C7, and C8). The C5b8 complex is expanded with $\mathrm{C} 9$ to form the MAC. MAC binds and permeabilizes bacterial walls (e.g. Neisseria), thereby killing the microorganism. Eculizumab is a long-

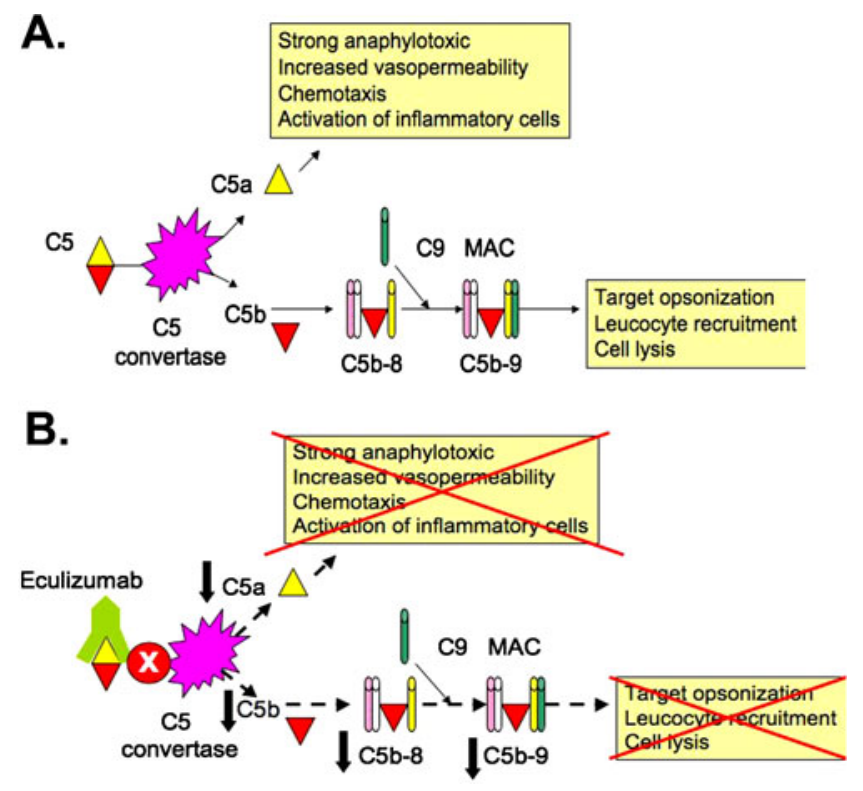

Fig. 2 Site of action of eculizumab. a Complement C5 is split by C5 convertase into $\mathrm{C} 5 \mathrm{a}$ and $\mathrm{C} 5 \mathrm{~b}$. C5a increases the permeability of blood vessels and attracts inflammatory cells by chemotaxis. $\mathrm{C} 5 \mathrm{~b}$ binds to other complement components (C6, C7, and C8). The C5b-8 complex is expanded with $\mathrm{C} 9$ to form the MAC. MAC binds and permeabilizes bacterial walls (e.g. Neisseria), thereby killing the microorganism. b Eculizumab is a long-acting humanized monoclonal antibody targeted against complement $\mathrm{C} 5$. It inhibits the cleavage of $\mathrm{C} 5$ into $\mathrm{C} 5 \mathrm{a}$ and $\mathrm{C} 5 \mathrm{~b}$ and hence inhibits deployment of the terminal complement system including the formation of MAC

acting humanized monoclonal antibody targeted against complement C5 (Fig. 2b) [118]. The plasma half-life is estimated to be about 11 days (personal communication with Alexion Pharmaceuticals). It inhibits the cleavage of $\mathrm{C} 5$ into $\mathrm{C} 5 \mathrm{a}$ and $\mathrm{C} 5 \mathrm{~b}$ and hence inhibits deployment of the terminal complement system including the formation of MAC.

\section{Efficacy of eculizumab in aHUS}

Five aHUS patients treated with eculizumab have been reported in the literature thus far [100, 103, 111-113]. Two patients have been treated in the pre-transplantation setting $[111,112]$ while the remaining three have received therapy post-transplantation $[100,103]$. In addition to the aforementioned five cases reported in the literature, an additional 14 patients have been treated with eculizumab, ten of whom achieved stable remission [4]. Of those reported and receiving treatment in the pre-transplantation setting, the first report was that of an 18-month-old male infant with congenital aHUS who had frequently relapsing aHUS [111]. Following the development of resistance to plasma therapy, a fourth relapse at 18 months of age was treated with weekly eculizumab at $300 \mathrm{mg}$ doses weekly for 
3 weeks, which was then followed by $600 \mathrm{mg}$ every 2 weeks thereafter. An improvement in the hematological and biochemical parameters was noted within $48 \mathrm{~h}$ of initiation of therapy and subsequently, plasma therapy was discontinued within the first week of eculizumab therapy. While a genetic defect in complement regulation was not identified in this infant and the hematological parameters improved just prior to the initiation of therapy, additional evidence for the beneficial effects of eculizumab in acute aHUS were recently reported in an adolescent with unclassified aHUS [63]. PEX was initially effective in facilitating the temporary improvement of renal function. On tapering the plasma exchanges to three times per week, aHUS activity progressed to ESRD. After 12 weeks, eculizumab was initiated and was effective in terminating the microangiopathic hemolytic process in two aHUS relapses [112]. However, after normalization of complement activity, aHUS recurred and ultimately led to anuric ESRD. A similarly beneficial experience has been reported in three renal transplant patients who experienced aHUS recurrence $[100,103,113]$. The first was a 30-year-old female with a combined CFH mutation (Y475S) and CFHR1 deletion [113]. She was treated with $600 \mathrm{mg}$ of eculizumab after her renal function deteriorated following failure of PEX initiated for recurrence of aHUS in a second allograft. She had lost her first allograft due to disease recurrence that was resistant to plasma 7 years earlier. Following commencement of eculizumab, the transplant function recovered with resolution of the total complement hemolytic activity and 8 months later, the patient's renal graft function is stable at the time of reporting [113]. Since this initial report, a further two cases have been reported. A 17-year-old girl with aHUS associated with a CFH mutation (S1191L) was plasma-dependent and successfully treated with eculizumab following the development of severe allergic reactions to plasma after her third allograft [20]. The fifth reported case treated with eculizumab is that of a 42-year-old woman with a heterozygous gain-offunction mutation (R570Q) in the C3 gene [103]. Following aHUS recurrence in her second renal allograft, she underwent intensive PEX to which she responded. However, PEX was discontinued as she experienced side-effects of diarrhea and fatigue. Treatment with eculizumab was initiated 4 days after the final session. She received four doses of eculizumab, $900 \mathrm{mg}$ IV every week, followed by a maintenance dose of $1,200 \mathrm{mg}$ every 2 weeks. After 7 months of eculizumab treatment, and without concomitant plasmapheresis, schistocytes decreased to $0.5 \%$, haptoglobin increased to within normal limits, creatinine levels stabilized, and no further episodes of diarrhea were reported. The need for blood transfusions was significantly reduced and they were stopped 4 months after continued eculizumab treatment. Therefore, clearly there is a role in the event of recurrence of aHUS. Whether a role exists for prophylactic eculizumab in the prevention of recurrence and thereafter its safety will have to be determined in future studies. Duration of therapy should be determined by the maintenance of remission of hemolysis and thrombocytopenia. In the current trials involving adolescents and adults, eculizumab will be provided for 6 months. Enrollment has just been completed and the results of the study are anticipated later this year. It is likely that the required duration of therapy will vary from patient to patient depending on the underlying complement defects.

\section{Dosage and administration}

Eculizumab is administered as an intravenous infusion and pharmacodynamic assays demonstrate that inhibition of C5 sufficient to prevent hemolysis occurs at eculizumab plasma concentrations in excess of $35 \mu \mathrm{g} / \mathrm{ml}$ [119]. Eculizumab (Soliris $\odot$, Alexion Pharmaceuticals) is administered as an infusion in adults at a dose of $600 \mathrm{mg}$ over 25 to $45 \mathrm{~min}$ with therapeutic doses of the drug achieved within $1 \mathrm{~h}$ of infusion. The frequency of administration can be weekly and the dose further increased to $900 \mathrm{mg}$ in adults in the fifth week. Thereafter, maintenance doses can be administered on an alternate weekly basis at $900 \mathrm{mg}$. Currently, there are no dosage recommendations for children under 12 years of age. However, with the advent of trials due to commence later this year, in younger children at acute presentation and in the pre-transplantation setting, guidelines for appropriate dosage for this age-group may be further developed.

\section{Adverse effects}

The main side-effects of therapy are an increased susceptibility to meningococcal infection as a result of MAC inhibition. MAC plays a crucial role in eliminating neisserial infections and defects in components of MAC are strongly associated with recurrent bacterial infections involving encapsulated Gram-positive or Gram-negative organisms such as neisserial and pneumococcal infections. It is advisable that patients carry a special card stating the risks and symptoms of susceptible infections such as Neisseria meningitidis when they are receiving treatment with eculizumab. Patients should be vaccinated against Neisseria meningitidis at least 2 weeks before treatment with eculizumab and revaccination is also recommended according to current guidelines. While antibodies will be generated following immunization, they will be of reduced efficacy as partly their action will rely on the terminal complement pathway. As a result, prophylactic antibiotics should also be considered for the duration of the treatment. 


\section{Clinical trials}

Owing to the reported benefits of eculizumab in individual cases of aHUS, its efficacy is currently being evaluated in a number of controlled clinical trials (ClinicalTrials.gov numbers NCT00844545, NCT00844428, NCT008838513, NCT00844844). Of these, one trial is an open-label controlled trial of eculizumab in adolescent patients (aged 12-18 years) with plasma therapy-sensitive aHUS (NCT00844428). This study is currently in phase II with recruitment just recently completed. The treatment period is for 6 months with analysis of results expected by the end of this year. Eligibility criteria can be found on the Web site: http://clinicaltrials.gov/ct2/show/NCT00844428. A second trial is determining the efficacy in adolescent patients with plasma therapy-resistant aHUS (NCT00844844). Resistance to plasma therapy is defined as a decrease in platelet count despite at least four plasma therapy (PT) treatments in the first week immediately prior to screening (screening platelet count, $150 \times 10^{9} / 1$ and at least $25 \%$ lower than remission platelet count or if remission counts not available, screening platelet count $\left.<75 \times 10^{9} / 1\right)$. Details of related adult studies can be found on the following Web site: http://clinicaltrials.gov/ ct2/show/NCT008838513 (adult patients with therapysensitive aHUS) and http://clinicaltrials.gov/ct2/show/ NCT00844545 (adult patients with therapy-resistant aHUS). Primary outcome measures include the assessment of the efficacy of eculizumab in reducing TMA while secondary outcome measures include additional efficacy endpoints related to manifestations of TMA, pharmacokinetics and pharmacodynamics of eculizumab in patients with aHUS, overall safety, and tolerability of eculizumab. Inclusion and exclusion criteria are as outlined in Tables 4 and 5. It is hoped that further trials addressing the efficacy and

Table 4 Criteria for assessment of the efficacy of eculizumab in adolescents with plasma therapy-sensitive aHUS (NCT00844428)

\section{Inclusion criteria}

1. Male or female patients from 12 and up to 18 years of age who have been diagnosed with atypical hemolytic uremic syndrome (aHUS)

2. Patients must be receiving plasma therapy (PT) for aHUS

3. Platelet count pre-PT baseline set-point (collected immediately prior to the qualifying PT episode) is within $75 \%$ of the average of the pre-PT platelet counts collected at screening and during the observation period

4. Diagnosis of aHUS

5. Lactate dehydrogenase (LDH) level $\geq$ upper limit of normal (ULN)

6. Creatinine level $\geq \mathrm{ULN}$ for age

7. Female patients of childbearing potential must be practicing an effective, reliable, and medically acceptable contraceptive regimen during the entire duration of the study, including the follow-up period

8. Patient's parents/legal guardian must be willing and able to give written informed consent and patient must be willing to give written informed assent

9. Able and willing to comply with study procedures

Exclusion criteria

1. ADAMTS13 inhibitor or deficiency (i.e. ADAMTS13 activity $<5 \%$ ) as measured at the screening visit

2. Malignancy

3. Typical HUS (Shiga toxin + )

4. Known HIV infection

5. Identified drug exposure-related HUS

6. Infection-related HUS

7. Presence or suspicion of active and untreated systemic bacterial infection that, in the opinion of the investigator, confounds an accurate diagnosis of aHUS or impedes the ability to manage the aHUS disease

8. Pregnancy or lactation

9. Unresolved meningococcal disease

10. Known systemic lupus erythematosus (SLE) or antiphospholipid antibody positivity or syndrome

11. Any medical or psychological condition that, in the opinion of the investigator, could increase the patient's risk by participating in the study or confound the outcome of the study

12. Patients receiving intravenous immunoglobulin (IVIG) or rituximab therapy

13. Patients receiving other immunosuppressive therapies such as steroids, mTOR inhibitors, or FK506 inhibitors are excluded unless: (1) part of a post-transplant anti-rejection regime, (2) patient has confirmed anti-CFH antibody requiring immunosuppressive therapy, and (3) dose of such medications have been unchanged for at least 4 weeks prior to the screening period

14. Patients receiving erythrocyte stimulating agents (ESAs) unless already on a stable dose for at least 4 weeks prior to the screening period

15. Participation in any other investigational drug trial or exposure to other investigational agent, device, or procedures beginning 4 weeks prior to screening and throughout the entire trial 
Table 5 Criteria for assessment of the efficacy of eculizumab in adolescents with plasma therapy-resistant aHUS (NCT00844844)

Inclusion criteria

1. Male or female patients up to 18 years of age who have been diagnosed with atypical hemolytic uremic syndrome (aHUS)

2. Decrease in platelet count despite at least four plasma therapy (PT) treatments in the first week immediately prior to screening Screening platelet count, $150 \times 10^{9} / 1$ and at least $25 \%$ lower than remission platelet count or

if remission counts not available, screening platelet count $<75 \times 10^{9} / 1$

3. Diagnosis of aHUS

4. Lactate dehydrogenase (LDH) level $\geq \mathrm{ULN}$

5. Creatinine level $\geq \mathrm{ULN}$ for age

6. Female patients of childbearing potential must be practicing an effective, reliable, and medically acceptable contraceptive regimen during the entire duration of the study, including the follow-up period

7. Patient's parents/legal guardian must be willing and able to give written informed consent and patient must be willing to give written informed assent

8. Able and willing to comply with study procedures

Exclusion criteria

1. ADAMTS13 inhibitor or deficiency (i.e. ADAMTS13 activity $<5 \%$ ) as measured at the screening visit

2. Malignancy

3. Typical HUS (Shiga toxin + )

4. Known HIV infection

5. Identified drug exposure-related HUS

6. Infection-related HUS

7. Renal function status requiring chronic dialysis

8. Presence or suspicion of active and untreated systemic bacterial infection that, in the opinion of the investigator, confounds an accurate diagnosis of aHUS or impedes the ability to manage the aHUS disease

9. Pregnancy or lactation

10. Unresolved meningococcal disease

11. Known systemic lupus erythematosus (SLE) or antiphospholipid antibody positivity or syndrome

12. Any medical or psychological condition that, in the opinion of the investigator, could increase the patient's risk by participating in the study or confound the outcome of the study

13. Patients receiving IVIG or rituximab therapy

14. Patients receiving other immunosuppressive therapies such as steroids, mTOR inhibitors, or FK506 inhibitors are excluded unless: (1) part of a post-transplant anti-rejection regime, (2) patient has confirmed anti-CFH antibody requiring immunosuppressive therapy, and (3) dose of such medications have been unchanged for at least 4 weeks prior to the screening period

15. Patients receiving erythrocyte stimulating agents (ESAs) unless already on a stable dose for at least 4 weeks prior to the screening period

16. Participation in any other investigational drug trial or exposure to other investigational agent, device, or procedures beginning 4 weeks prior to screening and throughout the entire trial

determining appropriate dosage will be developed for patients less than 12 years of age in the near future both in the setting of acute presentation as well as the peritransplantation period.

\section{Conclusions}

Atypical hemolytic uremic syndrome is a heterogeneous disease in which defective complement regulation currently accounts for around $50 \%$ of cases. Defects in more than one complement regulator are frequently present in many aHUS cases and thereby pose a significant therapeutic challenge. As a result, targeting the final effector pathway in complement activation may provide a more effective strategy in modifying disease progression. Recent reports propose an efficacious role for eculizumab in the management of aHUS. Results of the recently completed trial in adolescents are eagerly awaited. Enrollment of childhood cases of aHUS in a much anticipated trial is expected to commence later this year. Within the peri-transplantation setting, it will be important to determine the role of prophylactic eculizumab in the prevention of recurrence of aHUS.

\section{Multiple-choice questions}

(Answers appear following the reference list)

1. Atypical hemolytic uremic syndrome is caused by regulatory defects in:

a. The mannose-binding lectin pathway

b. The alternative complement pathway 
c. The classical complement pathway

d. T-cell function

2. Which of the following is NOT a feature of complement activation?
a. Low $\mathrm{C} 3$ levels
b. High $\mathrm{C} 3$ levels
c. High C3d levels
d. High iC3b levels

3. Which of the following defects in complement regulation have NOT been described in atypical hemolytic uremic syndrome?
a. Factor $\mathrm{H}$ deficiency
b. Factor B deficiency
c. Factor I deficiency
d. C3 deficiency

4. Which of the following is NOT a function of factor $\mathrm{H}$ ?
a. Acts as co-factor to factor I in the proteolytic cleavage of $\mathrm{C} 3 \mathrm{~b}$ to $\mathrm{iC} 3 \mathrm{~b}$
b. Binds to $\mathrm{C} 3 \mathrm{~b}$ and blocks the formation of the $\mathrm{C} 3$ convertases
c. Factor $\mathrm{H}$ inhibits the dissociation of the $\mathrm{C} 3$ convertases
d. Factor $\mathrm{H}$ binds sialic acid

5. Which of the following statements regarding factor I function is INCORRECT?
a. Factor $\mathrm{I}$ is a serine protease
b. Factor I inactivates $\mathrm{C} 3 \mathrm{~b}$ via the cleavage of the $\mathrm{C} 3$ $\alpha$-chain
c. Factor I inactivates $\mathrm{C} 3 \mathrm{~b}$ via the cleavage of the $\mathrm{C} 3$ $\beta$-chain
d. Factor I cleaves iC $3 b$ into $\mathrm{C} 3 \mathrm{c}$ and $\mathrm{C} 3 \mathrm{dg}$ using CR1 as a cofactor

6. Renal thrombotic microangiopathy is a feature of atypical hemolytic uremic syndrome and is associated with the following:
a. Mutations in the $\mathrm{N}$-terminus of factor $\mathrm{H}$
b. Mutations in the $\mathrm{C}$-terminus of factor $\mathrm{H}$
c. Inactivation of the C5-9 terminal attack complex
d. Inactivation of the $\mathrm{iC} 3 \mathrm{~b}$ complex

7. Current treatment modalities for atypical hemolytic uremic syndrome DO NOT include:
a. Plasmapheresis
b. Plasma infusion
c. Factor $\mathrm{Q}$ concentrate
d. Rituximab

8. The half-life of circulating factor $\mathrm{H}$ is
a. 1 day
b. 6 days
c. 7 days
d. 10 days

9. Rituximab has been reported to be effective in the peri-transplantation management of atypical hemolytic uremic syndrome associated with the following defect in complement regulation:
a. Factor I mutation
b. Factor $\mathrm{H}$ autoantibodies
c. Factor B mutation
d. Factor $\mathrm{H}$ mutation

10. Eculizumab has recently been reported to be effective in acute aHUS. Which of the following is TRUE regarding its mechanism of action?
a. Promotes cleavage of $\mathrm{C} 3$ to $\mathrm{C} 3 \mathrm{~b}$
b. Promotes cleavage of $\mathrm{C} 5$ to $\mathrm{C} 5 \mathrm{~b}$
c. Prevents cleavage of $\mathrm{C} 5$ to $\mathrm{C} 5 \mathrm{~b}$
d. Promotes cleavage of $\mathrm{iC} 3 \mathrm{~b}$ to $\mathrm{C} 3 \mathrm{dg}$

11. Which of the following is NOT an inclusion criterion for the current clinical trial of eculizumab in atypical hemolytic uremic syndrome:
a. Adolescents aged $12-17$ years of age
b. Adults $>18$ years of age
c. Children aged 2-12 years of age
d. Assured diagnosis of atypical hemolytic uremic syndrome within 2 weeks of screening

\section{References}

1. Karpman D, Landau D, Loirat C, Proesmans W, Remuzzi G, Rizzoni G, Taylor CM, Van de Kar N, Zimmerhackl LB (2006) A classification of hemolytic uremic syndrome and thrombotic thrombocytopenic purpura and related disorders. Kidney Int 70:423-431

2. Karmali MA, Petric M, Lim C, Fleming PC, Steele BT (1983) Escherichia coli cytotoxin, haemolytic-uraemic syndrome, and haemorrhagic colitis. Lancet 2:1299-1300

3. Ariceta G, Besbas N, Johnson S, Karpman D, Landau D, Licht C, Loirat C, Pecoraro C, Taylor CM, Van de Kar N, Vandewalle J, Zimmerhackl LB (2009) Guideline for the investigation and initial therapy of diarrhea-negative hemolytic uremic syndrome. Pediatr Nephrol 24:687-696

4. Noris M, Remuzzi G (2005) Genetic abnormalities of complement regulators in hemolytic uremic syndrome: how do they affect patient management? Nat Clin Pract Nephrol 1:2-3

5. Noris M, Remuzzi G (2009) Atypical hemolytic-uremic syndrome. N Engl J Med 361:1676-1687

6. Taylor CM, Machin S, Wigmore SJ, Goodship TH (2010) Clinical practice guidelines for the management of atypical haemolytic uraemic syndrome in the United Kingdom. Br J Haematol 148:37-47

7. Caprioli J, Bettinaglio P, Zipfel PF, Amadei B, Daina E, Gamba S, Skerka C, Marziliano N, Remuzzi G, Noris M (2001) The molecular basis of familial hemolytic uremic syndrome: mutation analysis of factor $\mathrm{H}$ gene reveals a hot spot in short consensus repeat 20. J Am Soc Nephrol 12:297-307

8. Caprioli J, Castelletti F, Bucchioni S, Bettinaglio P, Bresin E, Pianetti G, Gamba S, Brioschi S, Daina E, Remuzzi G, Noris M (2003) Complement factor $\mathrm{H}$ mutations and gene polymorphisms 
in haemolytic uraemic syndrome: the C-257T, the A2089G and the G2881T polymorphisms are strongly associated with the disease. Hum Mol Genet 12:3385-3395

9. Dragon-Durey MA, Fremeaux-Bacchi V, Loirat C, Blouin J, Niaudet P, Deschenes G, Coppo P, Herman Fridman W, Weiss L (2004) Heterozygous and homozygous factor $\mathrm{h}$ deficiencies associated with hemolytic uremic syndrome or membranoproliferative glomerulonephritis: report and genetic analysis of 16 cases. J Am Soc Nephrol 15:787-795

10. Manuelian T, Hellwage J, Meri S, Caprioli J, Noris M, Heinen S, Jozsi M, Neumann HP, Remuzzi G, Zipfel PF (2003) Mutations in factor $\mathrm{H}$ reduce binding affinity to $\mathrm{C} 3 \mathrm{~b}$ and heparin and surface attachment to endothelial cells in hemolytic uremic syndrome. J Clin Invest 111:1181-1190

11. Perez-Caballero D, Gonzalez-Rubio C, Gallardo ME, Vera M, Lopez-Trascasa M, Rodriguez de Cordoba S, Sanchez-Corral P (2001) Clustering of missense mutations in the C-terminal region of factor $\mathrm{H}$ in atypical hemolytic uremic syndrome. Am J Hum Genet 68:478-484

12. Venables JP, Strain L, Routledge D, Bourn D, Powell HM, Warwicker P, Diaz-Torres ML, Sampson A, Mead P, Webb M, Pirson Y, Jackson MS, Hughes A, Wood KM, Goodship JA, Goodship TH (2006) Atypical haemolytic uraemic syndrome associated with a hybrid complement gene. PLoS Med 3:e431

13. Warwicker P, Goodship TH, Donne RL, Pirson Y, Nicholls A, Ward RM, Turnpenny P, Goodship JA (1998) Genetic studies into inherited and sporadic hemolytic uremic syndrome. Kidney Int 53:836-844

14. Bienaime F, Dragon-Durey MA, Regnier CH, Nilsson SC, Kwan WH, Blouin J, Jablonski M, Renault N, Rameix-Welti MA, Loirat C, Sautes-Fridman C, Villoutreix BO, Blom AM, Fremeaux-Bacchi V (2010) Mutations in components of complement influence the outcome of factor I-associated atypical hemolytic uremic syndrome. Kidney Int 77:339-349

15. Chan MR, Thomas CP, Torrealba JR, Djamali A, Fernandez LA, Nishimura CJ, Smith RJ, Samaniego MD (2009) Recurrent atypical hemolytic uremic syndrome associated with factor I mutation in a living-related renal transplant recipient. Am J Kidney Dis 53:321-326

16. Cruzado JM, de Cordoba SR, Melilli E, Bestard O, Rama I, Sanchez-Corral P, Lopez-Trascasa M, Navarro I, Torras J, Goma M, Grinyo JM (2009) Successful renal transplantation in a patient with atypical hemolytic uremic syndrome carrying mutations in both factor I and MCP. Am J Transplant 9:14771483

17. Esparza-Gordillo J, Jorge EG, Garrido CA, Carreras L, LopezTrascasa M, Sanchez-Corral P, de Cordoba SR (2006) Insights into hemolytic uremic syndrome: segregation of three independent predisposition factors in a large, multiple affected pedigree. Mol Immunol 43:1769-1775

18. Fremeaux-Bacchi V, Dragon-Durey MA, Blouin J, Vigneau C, Kuypers D, Boudailliez B, Loirat C, Rondeau E, Fridman WH (2004) Complement factor I: a susceptibility gene for atypical haemolytic uraemic syndrome. J Med Genet 41:e84

19. Kavanagh D, Kemp EJ, Mayland E, Winney RJ, Duffield JS, Warwick G, Richards A, Ward R, Goodship JA, Goodship TH (2005) Mutations in complement factor I predispose to development of atypical hemolytic uremic syndrome. J Am Soc Nephrol $16: 2150-2155$

20. Kavanagh D, Richards A, Noris M, Hauhart R, Liszewski MK, Karpman D, Goodship JA, Fremeaux-Bacchi V, Remuzzi G, Goodship TH, Atkinson JP (2008) Characterization of mutations in complement factor I (CFI) associated with hemolytic uremic syndrome. Mol Immunol 45:95-105

21. Le Quintrec M, Zuber J, Noel LH, Thervet E, Fremeaux-Bacchi V, Niaudet P, Fridman WH, Legendre C, Dragon-Durey MA
(2009) Anti-factor H autoantibodies in a fifth renal transplant recipient with atypical hemolytic and uremic syndrome. Am J Transplant 9:1223-1229

22. Nilsson SC, Kalchishkova N, Trouw LA, Fremeaux-Bacchi V, Villoutreix BO, Blom AM (2009) Mutations in complement factor I as found in atypical hemolytic uremic syndrome lead to either altered secretion or altered function of factor I. Eur $\mathrm{J}$ Immunol 40:172-185

23. Ponce-Castro IM, Gonzalez-Rubio C, Delgado-Cervino EM, Abarrategui-Garrido C, Fontan G, Sanchez-Corral P, LopezTrascasa M (2008) Molecular characterization of complement factor I deficiency in two Spanish families. Mol Immunol 45:2764-2771

24. Sellier-Leclerc AL, Fremeaux-Bacchi V, Dragon-Durey MA, Macher MA, Niaudet P, Guest G, Boudailliez B, Bouissou F, Deschenes G, Gie S, Tsimaratos M, Fischbach M, Morin D, Nivet H, Alberti C, Loirat C (2007) Differential impact of complement mutations on clinical characteristics in atypical hemolytic uremic syndrome. J Am Soc Nephrol 18:2392-2400

25. Jozsi M, Licht C, Strobel S, Zipfel SL, Richter H, Heinen S, Zipfel PF, Skerka C (2008) Factor H autoantibodies in atypical hemolytic uremic syndrome correlate with CFHR1/CFHR3 deficiency. Blood 111:1512-1514

26. Heinen S, Hartmann A, Lauer N, Wiehl U, Dahse HM, Schirmer S, Gropp K, Enghardt T, Wallich R, Halbich S, Mihlan M, Schlotzer-Schrehardt U, Zipfel PF, Skerka C (2009) Factor Hrelated protein 1 (CFHR-1) inhibits complement C5 convertase activity and terminal complex formation. Blood 114:2439-2447

27. Couzi L, Contin-Bordes C, Marliot F, Sarrat A, Grimal P, Moreau JF, Merville P, Fremeaux-Bacchi V (2008) Inherited deficiency of membrane cofactor protein expression and varying manifestations of recurrent atypical hemolytic uremic syndrome in a sibling pair. Am J Kidney Dis 52:e5-e9

28. Fremeaux-Bacchi V, Arzouk N, Ferlicot S, Charpentier B, Snanoudj R, Durrbach A (2007) Recurrence of HUS due to CD46/MCP mutation after renal transplantation: a role for endothelial microchimerism. Am J Transplant 7:2047-2051

29. Fremeaux-Bacchi V, Moulton EA, Kavanagh D, Dragon-Durey MA, Blouin J, Caudy A, Arzouk N, Cleper R, Francois M, Guest G, Pourrat J, Seligman R, Fridman WH, Loirat C, Atkinson JP (2006) Genetic and functional analyses of membrane cofactor protein (CD46) mutations in atypical hemolytic uremic syndrome. J Am Soc Nephrol 17:2017-2025

30. Noris M, Brioschi S, Caprioli J, Todeschini M, Bresin E, Porrati F, Gamba S, Remuzzi G (2003) Familial haemolytic uraemic syndrome and an MCP mutation. Lancet 362:1542-1547

31. Richards A, Kemp EJ, Liszewski MK, Goodship JA, Lampe AK, Decorte R, Muslumanoglu MH, Kavukcu S, Filler G, Pirson Y, Wen LS, Atkinson JP, Goodship TH (2003) Mutations in human complement regulator, membrane cofactor protein (CD46), predispose to development of familial hemolytic uremic syndrome. Proc Natl Acad Sci USA 100:12966-12971

32. Goicoechea de Jorge E, Harris CL, Esparza-Gordillo J, Carreras L, Arranz EA, Garrido CA, Lopez-Trascasa M, Sanchez-Corral P, Morgan BP, Rodriguez de Cordoba S (2007) Gain-of-function mutations in complement factor B are associated with atypical hemolytic uremic syndrome. Proc Natl Acad Sci USA 104:240 245

33. Kavanagh D, Goodship TH, Richards A (2006) Atypical haemolytic uraemic syndrome. Br Med Bull 77-78:5-22

34. Fremeaux-Bacchi V, Miller EC, Liszewski MK, Strain L, Blouin J, Brown AL, Moghal N, Kaplan BS, Weiss RA, Lhotta K, Kapur G, Mattoo T, Nivet H, Wong W, Gie S, Hurault de Ligny B, Fischbach M, Gupta R, Hauhart R, Meunier V, Loirat C, Dragon-Durey MA, Fridman WH, Janssen BJ, Goodship TH, Atkinson JP (2008) Mutations in 
complement $\mathrm{C} 3$ predispose to development of atypical hemolytic uremic syndrome. Blood 112:4948-4952

35. Lhotta K, Janecke AR, Scheiring J, Petzlberger B, Giner T, Fally V, Wurzner R, Zimmerhackl LB, Mayer G, Fremeaux-Bacchi V (2009) A large family with a gain-of-function mutation of complement $\mathrm{C} 3$ predisposing to atypical hemolytic uremic syndrome, microhematuria, hypertension and chronic renal failure. Clin J Am Soc Nephrol 4:1356-1362

36. Geelen J, van den Dries K, Roos A, van de Kar N, de Kat AC, Klasen I, Monnens L, van den Heuvel L (2007) A missense mutation in factor I (IF) predisposes to atypical haemolytic uraemic syndrome. Pediatr Nephrol 22:371-375

37. Skerka C, Jozsi M, Zipfel PF, Dragon-Durey MA, FremeauxBacchi V (2009) Autoantibodies in haemolytic uraemic syndrome (HUS). Thromb Haemost 101:227-232

38. Moore I, Strain L, Pappworth I, Kavanagh D, Barlow PN, Herbert AP, Schmidt CQ, Staniforth SJ, Holmes LV, Ward R, Morgan L, Goodship TH, Marchbank KJ (2010) Association of factor $\mathrm{H}$ autoantibodies with deletions of CFHR1, CFHR3, CFHR4 and with mutations in CFH, CFI, CD46, and C3 in patients with atypical haemolytic uraemic syndrome. Blood 115:379-387

39. Delvaeye M, Noris M, De Vriese A, Esmon CT, Esmon NL, Ferrell G, Del-Favero J, Plaisance S, Claes B, Lambrechts D, Zoja C, Remuzzi G, Conway EM (2009) Thrombomodulin mutations in atypical hemolytic-uremic syndrome. N Engl J Med 361:345-357

40. Nishimura T, Myles T, Piliponsky AM, Kao PN, Berry GJ, Leung LL (2007) Thrombin-activatable procarboxypeptidase $\mathrm{B}$ regulates activated complement $\mathrm{C} 5 \mathrm{a}$ in vivo. Blood 109:1992-1997

41. Loirat C, Noris M, Fremeaux-Bacchi V (2008) Complement and the atypical hemolytic uremic syndrome in children. Pediatr Nephrol 23:1957-1972

42. Scheiring J, Rosales A, Zimmerhackl LB (2009) Clinical practice. Today's understanding of the haemolytic uraemic syndrome. Eur J Pediatr 169:7-13

43. Zipfel PF, Skerka C (2009) Complement regulators and inhibitory proteins. Nat Rev Immunol 9:729-740

44. Kaplan BS, Chesney RW, Drummond KN (1975) Hemolytic uremic syndrome in families. N Engl J Med 292:1090-1093

45. Kaplan BS (1977) Hemolytic uremic syndrome with recurrent episodes: an important subset. Clin Nephrol 8:495-498

46. Caprioli J, Noris M, Brioschi S, Pianetti G, Castelletti F, Bettinaglio P, Mele C, Bresin E, Cassis L, Gamba S, Porrati F, Bucchioni S, Monteferrante G, Fang CJ, Liszewski MK, Kavanagh D, Atkinson JP, Remuzzi G (2006) Genetics of HUS: the impact of MCP, CFH, and IF mutations on clinical presentation, response to treatment, and outcome. Blood 108:1267-1279

47. Loirat C, Fremeaux-Bacchi V (2008) Hemolytic uremic syndrome recurrence after renal transplantation. Pediatr Transplant 12:619-629

48. Esparza-Gordillo J, Goicoechea de Jorge E, Buil A, Carreras Berges L, Lopez-Trascasa M, Sanchez-Corral P, Rodriguez de Cordoba S (2005) Predisposition to atypical hemolytic uremic syndrome involves the concurrence of different susceptibility alleles in the regulators of complement activation gene cluster in 1q32. Hum Mol Genet 14:703-712

49. Pickering MC, Cook HT (2008) Translational mini-review series on complement factor $\mathrm{H}$ : renal diseases associated with complement factor $\mathrm{H}$ : novel insights from humans and animals. Clin Exp Immunol 151:210-230

50. Medzhitov R, Janeway CA Jr (2002) Decoding the patterns of self and nonself by the innate immune system. Science 296:298-300
51. Ogden CA, Elkon KB (2006) Role of complement and other innate immune mechanisms in the removal of apoptotic cells. Curr Dir Autoimmun 9:120-142

52. Rooijakkers SH, van Strijp JA (2007) Bacterial complement evasion. Mol Immunol 44:23-32

53. Zipfel PF, Wurzner R, Skerka C (2007) Complement evasion of pathogens: common strategies are shared by diverse organisms. Mol Immunol 44:3850-3857

54. Pangburn MK, Schreiber RD, Muller-Eberhard HJ (1977) Human complement $\mathrm{C} 3 \mathrm{~b}$ inactivator: isolation, characterization, and demonstration of an absolute requirement for the serum protein beta1 $\mathrm{H}$ for cleavage of $\mathrm{C} 3 \mathrm{~b}$ and $\mathrm{C} 4 \mathrm{~b}$ in solution. J Exp Med 146:257-270

55. Weiler JM, Daha MR, Austen KF, Fearon DT (1976) Control of the amplification convertase of complement by the plasma protein beta1H. Proc Natl Acad Sci USA 73:3268-3272

56. Whaley K, Ruddy S (1976) Modulation of the alternative complement pathways by beta $1 \mathrm{H}$ globulin. J Exp Med 144:1147-1163

57. Zipfel PF, Skerka C (1999) FHL-1/reconectin: a human complement and immune regulator with cell-adhesive function. Immunol Today 20:135-140

58. Remuzzi G, Misiani R, Marchesi D, Livio M, Mecca G, de Gaetano G, Donati MB (1978) Haemolytic-uraemic syndrome: deficiency of plasma factor(s) regulating prostacyclin activity? Lancet 2:871-872

59. Kleanthous H, Smith HR, Scotland SM, Gross RJ, Rowe B, Taylor CM, Milford DV (1990) Haemolytic uraemic syndromes in the British Isles, 1985-8: association with verocytotoxin producing Escherichia coli. Part 2: Microbiological aspects. Arch Dis Child 65:722-727

60. Saunders RE, Goodship TH, Zipfel PF, Perkins SJ (2006) An interactive Web database of factor $\mathrm{H}$-associated hemolytic uremic syndrome mutations: insights into the structural consequences of disease-associated mutations. Hum Mutat 27:21-30

61. Allford SL, Hunt BJ, Rose P, Machin SJ (2003) Guidelines on the diagnosis and management of the thrombotic microangiopathic haemolytic anaemias. Br J Haematol 120:556-573

62. Geraghty MT, Perlman EJ, Martin LS, Hayflick SJ, Casella JF, Rosenblatt DS, Valle D (1992) Cobalamin C defect associated with hemolytic-uremic syndrome. J Pediatr 120:934-937

63. Barz D, Budde U, Hellstern P (2002) Therapeutic plasma exchange and plasma infusion in thrombotic microvascular syndromes. Thromb Res 107(Suppl 1):S23-S27

64. von Baeyer H (2002) Plasmapheresis in thrombotic microangiopathy-associated syndromes: review of outcome data derived from clinical trials and open studies. Ther Apher 6:320-328

65. Bell WR, Braine HG, Ness PM, Kickler TS (1991) Improved survival in thrombotic thrombocytopenic purpura-hemolytic uremic syndrome. Clinical experience in 108 patients. N Engl J Med 325:398-403

66. Rizvi MA, Vesely SK, George JN, Chandler L, Duvall D, Smith JW, Gilcher RO (2000) Complications of plasma exchange in 71 consecutive patients treated for clinically suspected thrombotic thrombocytopenic purpura-hemolytic-uremic syndrome. Transfusion 40:896-901

67. Licht C, Weyersberg A, Heinen S, Stapenhorst L, Devenge J, Beck B, Waldherr R, Kirschfink M, Zipfel PF, Hoppe B (2005) Successful plasma therapy for atypical hemolytic uremic syndrome caused by factor $\mathrm{H}$ deficiency owing to a novel mutation in the complement cofactor protein domain 15. Am J Kidney Dis 45:415-421

68. Zurowska A, Zaluska-Lesniewska I, Hladny-Czerska W (2006) Successful prophylactic plasma infusions in recurrent atypical hemolytic-uremic syndrome. Przegl Lek 63(Suppl 3):223-225 
69. O'Shaughnessy DF, Atterbury C, Bolton Maggs P, Murphy M, Thomas D, Yates S, Williamson LM (2004) Guidelines for the use of fresh-frozen plasma, cryoprecipitate and cryosupernatant. Br J Haematol 126:11-28

70. Bircan Z, Toprak D, Kilicaslan I, Solakoglu S, Uysal V, Ponard D, Turker G (2004) Factor H deficiency and fibrillary glomerulopathy. Nephrol Dial Transplant 19:727-730

71. Brai M, Misiano G, Maringhini S, Cutaja I, Hauptmann G (1988) Combined homozygous factor $\mathrm{H}$ and heterozygous $\mathrm{C} 2$ deficiency in an Italian family. J Clin Immunol 8:50-56

72. Cho HY, Lee BS, Moon KC, Ha IS, Cheong HI, Choi Y (2007) Complete factor $\mathrm{H}$ deficiency-associated atypical hemolytic uremic syndrome in a neonate. Pediatr Nephrol 22:874-880

73. Fijen CA, Kuijper EJ, Te Bulte M, van de Heuvel MM, Holdrinet AC, Sim RB, Daha MR, Dankert J (1996) Heterozygous and homozygous factor $\mathrm{H}$ deficiency states in a Dutch family. Clin Exp Immunol 105:511-516

74. Levy M, Halbwachs-Mecarelli L, Gubler MC, Kohout G, Bensenouci A, Niaudet P, Hauptmann G, Lesavre P (1986) H deficiency in two brothers with atypical dense intramembranous deposit disease. Kidney Int 30:949-956

75. Nielsen HE, Christensen KC, Koch C, Thomsen BS, Heegaard NH, Tranum-Jensen J (1989) Hereditary, complete deficiency of complement factor $\mathrm{H}$ associated with recurrent meningococcal disease. Scand J Immunol 30:711-718

76. Ohali M, Shalev H, Schlesinger M, Katz Y, Kachko L, Carmi R, Sofer S, Landau D (1998) Hypocomplementemic autosomal recessive hemolytic uremic syndrome with decreased factor $\mathrm{H}$. Pediatr Nephrol 12:619-624

77. Pichette V, Querin S, Schurch W, Brun G, Lehner-Netsch G, Delage JM (1994) Familial hemolytic-uremic syndrome and homozygous factor $\mathrm{H}$ deficiency. Am J Kidney Dis 24:936941

78. Rougier N, Kazatchkine MD, Rougier JP, Fremeaux-Bacchi V, Blouin J, Deschenes G, Soto B, Baudouin V, Pautard B, Proesmans W, Weiss E, Weiss L (1998) Human complement factor $\mathrm{H}$ deficiency associated with hemolytic uremic syndrome. J Am Soc Nephrol 9:2318-2326

79. Thompson RA, Winterborn MH (1981) Hypocomplementaemia due to a genetic deficiency of beta $1 \mathrm{H}$ globulin. Clin Exp Immunol 46:110-119

80. Vaziri-Sani F, Holmberg L, Sjoholm AG, Kristoffersson AC, Manea M, Fremeaux-Bacchi V, Fehrman-Ekholm I, Raafat R, Karpman D (2006) Phenotypic expression of factor H mutations in patients with atypical hemolytic uremic syndrome. Kidney Int 69:981-988

81. Vogt BA, Wyatt RJ, Burke BA, Simonton SC, Kashtan CE (1995) Inherited factor $\mathrm{H}$ deficiency and collagen type III glomerulopathy. Pediatr Nephrol 9:11-15

82. Boyer O, Noel LH, Balzamo E, Guest G, Biebuyck N, Charbit M, Salomon R, Fremeaux-Bacchi V, Niaudet P (2008) Complement factor $\mathrm{H}$ deficiency and posttransplantation glomerulonephritis with isolated C3 deposits. Am J Kidney Dis 51:671-677

83. Landau D, Shalev H, Levy-Finer G, Polonsky A, Segev Y, Katchko L (2001) Familial hemolytic uremic syndrome associated with complement factor $\mathrm{H}$ deficiency. J Pediatr 138:412-417

84. Lapeyraque AL, Wagner E, Phan V, Clermont MJ, Merouani A, Fremeaux-Bacchi V, Goodship TH, Robitaille P (2008) Efficacy of plasma therapy in atypical hemolytic uremic syndrome with complement factor H mutations. Pediatr Nephrol 23:1363-1366

85. Sethi SK, Marie-Agnes DD, Thaker N, Hari P, Bagga A (2009) Hemolytic uremic syndrome due to homozygous factor $\mathrm{H}$ deficiency. Clin Exp Nephrol 13:526-530
86. Nathanson S, Fremeaux-Bacchi V, Deschenes G (2001) Successful plasma therapy in hemolytic uremic syndrome with factor H deficiency. Pediatr Nephrol 16:554-556

87. Davin JC, Olie KH, Verlaak R, Horuz F, Florquin S, Weening JJ, Groothoff JW, Strain L, Goodship TH (2006) Complement factor $\mathrm{H}$-associated atypical hemolytic uremic syndrome in monozygotic twins: concordant presentation, discordant response to treatment. Am J Kidney Dis 47:e27-e30

88. De S, Waters AM, Segal AO, Trautmann A, Harvey EA, Licht C (2010) Severe atypical HUS caused by CFH S1191L-case presentation and review of treatment options. Pediatr Nephrol 25:97-104

89. Filler G, Radhakrishnan S, Strain L, Hill A, Knoll G, Goodship TH (2004) Challenges in the management of infantile factor $\mathrm{H}$ associated hemolytic uremic syndrome. Pediatr Nephrol 19:908911

90. Gerber A, Kirchhoff-Moradpour AH, Obieglo S, Brandis M, Kirschfink M, Zipfel PF, Goodship JA, Zimmerhackl LB (2003) Successful (?) therapy of hemolytic-uremic syndrome with factor H abnormality. Pediatr Nephrol 18:952-955

91. Stratton JD, Warwicker P (2002) Successful treatment of factor H-related haemolytic uraemic syndrome. Nephrol Dial Transplant 17:684-685

92. Nathanson S, Ulinski T, Fremeaux-Bacchi V, Deschenes G (2006) Secondary failure of plasma therapy in factor $\mathrm{H}$ deficiency. Pediatr Nephrol 21:1769-1771

93. Dragon-Durey MA, Loirat C, Cloarec S, Macher MA, Blouin J, Nivet H, Weiss L, Fridman WH, Fremeaux-Bacchi V (2005) Anti-factor $\mathrm{H}$ autoantibodies associated with atypical hemolytic uremic syndrome. J Am Soc Nephrol 16:555-563

94. Jozsi M, Strobel S, Dahse HM, Liu WS, Hoyer PF, Oppermann M, Skerka C, Zipfel PF (2007) Anti factor H autoantibodies block C-terminal recognition function of factor $\mathrm{H}$ in hemolytic uremic syndrome. Blood 110:1516-1518

95. Strobel S, Hoyer PF, Mache CJ, Sulyok E, Liu WS, Richter H, Oppermann M, Zipfel PF, Jozsi M (2010) Functional analyses indicate a pathogenic role of factor $\mathrm{H}$ autoantibodies in atypical haemolytic uraemic syndrome. Nephrol Dial Transplant 25:136144

96. Abarrategui-Garrido C, Martinez-Barricarte R, Lopez-Trascasa M, de Cordoba SR, Sanchez-Corral P (2009) Characterization of complement factor H-related (CFHR) proteins in plasma reveals novel genetic variations of CFHR1 associated with atypical hemolytic uremic syndrome. Blood 114:4261-4271

97. Lee BH, Kwak SH, Shin JI, Lee SH, Choi HJ, Kang HG, Ha IS, Lee JS, Dragon-Durey MA, Choi Y, Cheong HI (2009) Atypical hemolytic uremic syndrome associated with complement factor $\mathrm{H}$ autoantibodies and CFHR1/CFHR3 deficiency. Pediatr Res 66:336-340

98. Waters AM, Pappworth I, Marchbank K, Bockenhauer D, Tullus K, Pickering MC, Strain L, Sebire N, Shroff R, Marks SD, Goodship TH, Rees L (2010) Successful renal transplantation in factor $\mathrm{H}$ autoantibody associated HUS with CFHR1 and 3 deficiency and CFH variant G2850T. Am J Transplant 10:168172

99. Kwon T, Dragon-Durey MA, Macher MA, Baudouin V, Maisin A, Peuchmaur M, Fremeaux-Bacchi V, Loirat C (2008) Successful pre-transplant management of a patient with anti-factor $\mathrm{H}$ autoantibodies-associated haemolytic uraemic syndrome. Nephrol Dial Transplant 23:2088-2090

100. Davin JC, Gracchi V, Bouts A, Groothoff J, Strain L, Goodship $\mathrm{T}$ (2010) Maintenance of kidney function following treatment with eculizumab and discontinuation of plasma exchange after a third kidney transplant for atypical hemolytic uremic syndrome associated with a CFH Mutation. Am J Kidney Dis 55:708-711 
101. Bresin E, Daina E, Noris M, Castelletti F, Stefanov R, Hill P, Goodship TH, Remuzzi G (2006) Outcome of renal transplantation in patients with non-Shiga toxin-associated hemolytic uremic syndrome: prognostic significance of genetic background. Clin J Am Soc Nephrol 1:88-99

102. Nilsson SC, Karpman D, Vaziri-Sani F, Kristoffersson AC, Salomon R, Provot F, Fremeaux-Bacchi V, Trouw LA, Blom AM (2007) A mutation in factor I that is associated with atypical hemolytic uremic syndrome does not affect the function of factor I in complement regulation. Mol Immunol 44:1835-1844

103. Chatelet V, Fremeaux-Bacchi V, Lobbedez T, Ficheux M, de Ligny BH (2009) Safety and long-term efficacy of eculizumab in a renal transplant patient with recurrent atypical hemolyticuremic syndrome. Am J Transplant 9:2644-2645

104. Jalanko H, Peltonen S, Koskinen A, Puntila J, Isoniemi H, Holmberg C, Pinomaki A, Armstrong E, Koivusalo A, Tukiainen E, Makisalo H, Saland J, Remuzzi G, de Cordoba S, Lassila R, Meri S, Jokiranta TS (2008) Successful liver-kidney transplantation in two children with aHUS caused by a mutation in complement factor H. Am J Transplant 8:216-221

105. Saland JM, Ruggenenti P, Remuzzi G (2009) Liver-kidney transplantation to cure atypical hemolytic uremic syndrome. J Am Soc Nephrol 20:940-949

106. Saland JM, Shneider BL, Bromberg JS, Shi PA, Ward SC, Magid MS, Benchimol C, Seikaly MG, Emre SH, Bresin E, Remuzzi G (2009) Successful split liver-kidney transplant for factor $\mathrm{H}$ associated hemolytic uremic syndrome. Clin J Am Soc Nephrol 4:201-206

107. Remuzzi G, Ruggenenti P, Codazzi D, Noris M, Caprioli J, Locatelli G, Gridelli B (2002) Combined kidney and liver transplantation for familial haemolytic uraemic syndrome. Lancet 359:1671-1672

108. Remuzzi G, Ruggenenti P, Colledan M, Gridelli B, Bertani A, Bettinaglio P, Bucchioni S, Sonzogni A, Bonanomi E, Sonzogni V, Platt JL, Perico N, Noris M (2005) Hemolytic uremic syndrome: a fatal outcome after kidney and liver transplantation performed to correct factor H gene mutation. Am J Transplant 5:1146-1150

109. Richards A, Kemp EJ, Liszewski MK, Goodship JA, Lampe AK, Decorte R, Muslumanoglu MH, Kavukcu S, Filler G, Pirson Y, Wen LS, Atkinson JP, Goodship TH (2003) Mutations in human complement regulator, membrane cofactor protein (CD46), predispose to development of familial hemolytic uremic syndrome. Proc Natl Acad Sci USA 100:12966-12971

110. Donne RL, Abbs I, Barany P, Elinder CG, Little M, Conlon P, Goodship TH (2002) Recurrence of hemolytic uremic syndrome after live-related renal transplantation associated with subsequent de novo disease in the donor. Am J Kidney Dis 40:E22
111. Gruppo RA, Rother RP (2009) Eculizumab for congenital atypical hemolytic-uremic syndrome. N Engl J Med 360:544546

112. Mache CJ, Acham-Roschitz B, Fremeaux-Bacchi V, Kirschfink M, Zipfel PF, Roedl S, Vester U, Ring E (2009) Complement inhibitor eculizumab in atypical hemolytic uremic syndrome. Clin J Am Soc Nephrol 4:1312-1316

113. Nurnberger J, Witzke O, Opazo Saez A, Vester U, Baba HA, Kribben A, Zimmerhackl LB, Janecke AR, Nagel M, Kirschfink M (2009) Eculizumab for atypical hemolytic-uremic syndrome. N Engl J Med 360:542-544

114. Hillmen P, Hall C, Marsh JC, Elebute M, Bombara MP, Petro BE, Cullen MJ, Richards SJ, Rollins SA, Mojcik CF, Rother RP (2004) Effect of eculizumab on hemolysis and transfusion requirements in paroxysmal nocturnal hemoglobinuria. N Eng J Med 350:552-559

115. Parker C (2009) Eculizumab for paroxysmal nocturnal haemoglobinuria. Lancet 373:759-767

116. Wagner E, Frank MM (2010) Therapeutic potential of complement modulation. Nat Rev Drug Discov 9:43-56

117. Rother RP, Rollins SA, Mojcik CF, Brodsky RA, Bell L (2007) Discovery and development of the complement inhibitor eculizumab for the treatment of paroxysmal nocturnal hemoglobinuria. Nat Biotechnol 25:1256-1264

118. Parker CJ, Kar S, Kirkpatrick P (2007) Eculizumab. Nat Rev Drug Discov 6:515-516

119. Dmytrijuk A, Robie-Suh K, Cohen MH, Rieves D, Weiss K, Pazdur R (2008) FDA report: eculizumab (Soliris) for the treatment of patients with paroxysmal nocturnal hemoglobinuria. Oncologist 13:993-1000

\section{Answers:}

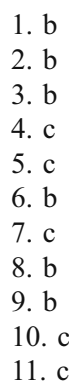

